К. М. ЛІСОВА

\title{
ГЕНЕТИЧНІ АСПЕКТИ НЕВИНОШУВАННЯ ВАГІТНОСТІ
}

\author{
Кафедра акушерства і гінекології (зав. - проф. О. М. Юзько) \\ ВДН3 «Буковинський державний медичний університет» <kalinovska@bsmu.edu.ua>
}

\begin{abstract}
Невиношування вагітності є наслідком впливу багатьох факторів. Ми проаналізували у вагітних з невиношуванням в анамнезі вплив гена невиношування на ембріометричні, ультразвукові, гормональні, імунологічні показники й оцінили його прогностичне значення. Основну групу (ОГ) становила 31 вагітна, у якої були клінічні ознаки невиношування даної або попередньої вагітності; контрольну групу (КГ) - 32 здорові вагітні, клініко-параклінічні показники яких були контролем для порівняння результатів обстеження вагітних ОГ. Проведено загальноклінічне та спеціальне акушерське обстеження (з'ясування скарг, збір анамнезу, загальносоматичний лікарський огляд, акушерське обстеження), біохімічне (визначення гормонів фетоплацентарного комплексу у сироватиі крові вагітних), ультразвукове, імунологічне, гістологічне дослідження плаценти, а також молекулярно-генетичне дослідження А1166C поліморфізмy гена AGTR1. Виявлено генетичну детермінованість невиношування. Поліморфізм A1166C гена AGTR1 розглядали як прогностичний маркер переривання вагітності в ранні терміни гестації та прееклампсії у другій половині вагітності. Достовірним маркером загрози переривання у вагітних був материнський генотип 1166 АС за геном AGTR1. Ризик виникнення клінічних проявів загрози переривання під час вагітності підвищувався у 5 разів, а при одночасному впливі всіх прогностичних факторів ризикy 6,25 раза. Виявлення генетичних маркерів невиношування вагітності дозволить проводити ранню корекцію даної патології $i$ запобігати перинатальним втратам.
\end{abstract}

Ключові слова: невиношування вагітності; генетичний маркер; генотип; прогностичний фактор; перериваня вагітності.

Вступ. Невиношування є частим ускладненням вагітності (від 14 до 24 \%), воно призводить до мимовільного викидня, тривалої загрози переривання вагітності, передчасних пологів та є однією 3 найчастіших причин перинатальної захворюваності (до 64 \%) і смертності [1]. Дослідженню впливу генетичних маркерів на перебіг вагітності присвячено багато наукових праць, в яких аналізується вплив материнського або плацентарного генотипу на ризик розвитку ускладнень вагітності [2]. Окремі поліморфні варіанти генів розглядають як прогностичні маркери підвищеного ризику переривання вагітності $[4,5]$. У зазначених працях не вивчали зв'язок біометричних показників ембріона і плода 3 урахуванням гормонального гомеостазу вагітних з генотипом матері [3]. Як наслідок, ізольоване використання прогностичних генетичних маркерів зменшило їх цінність та знизило можливість практичного застосування.

Мета дослідження - проаналізувати у вагітних 3 невиношуванням в анамнезі вплив гена невиношування на ембріометричні, ультразвукові, гормональні, імунологічні показники й оцінити його прогностичне значення.

Матеріали і методи. У процесі дослідження обстежено 31 вагітну 3 невиношуванням в анамнезі, які становили основну групу, контрольну групу - 32 здорові вагітні. При проведенні досліджень використано такі методи: загальноклінічне та спеціальне акушерське обстеження (з'ясування скарг, збір анамнезу, загальносоматичний лікарський огляд, акушерське обстеження), біохімічні (визначення гормонів фетоплацентарного комплексу у сироватці крові вагітних), імунологічні (визначення IL-2, IL-4), ультразвукові, гістологічні дослідження плаценти, генетичні дослідження, статистичні методи обробки результатів. Визначення гормонів (прогестерон, естрадіол, плацентарний лактоген, хоріонічний гонадотропін) здійснювали методом твердофазного імуноферментного аналізу. Використовували такі набори реактивів: «Стероид ИФА-прогестерон-01», «Плацентарний лактоген 
ИФА», «Гонадотропин ИФА-ХГч-1» виробництва ЗАО «Амкор Био», «Эстрадиол ИФА» виробництва ООО «Хема - Медика». Кількісне визначення рівня IL-2 та IL-4 в сироватці крові вагітних проводили за допомогою наборів реагентів «ProCon IL-2», «ProCon IL-4». Рівень імуноглобулінів (Ig) класів A, G, M у сироватці крові як показник функціональної активності В-ланки імунітету визначали методом простої радіальної імунодифузії в гелі за С. Mancini та співавт. Використовували стандартні моноспецифічні антисироватки Горьківського НДІ епідеміології та мікробіології. Гістологічне дослідження проводили на базі кафедри патологічної анатомії ВДНЗ «Буковинський державний медичний університет». Загальногістологічні дослідження проводили за стандартною схемою. 3 фіксованої в нейтральному формаліні тканини плаценти через усю товщу вирізали шість шматочків (2 - 3 краю, 2 - 3 парацентральної частини, 2 - 3 центральної зони плаценти). Матеріал обробляли в парафіновій заливці, зрізи забарвлювали гематоксилін-еозином та пікрофуксином за ван-Гізоном. Стан внутрішньоутробного ембріона/плода оцінювали за даними ультразвукової фето- і плацентометрії. Ультразвукове сканування виконували на апараті SONOACE 8800 «GAI MT» 3 використанням конвексного датчика потужністю від 3,5 до 7,5 Мгц. Матеріалом для молекулярно-генетичного дослідження була периферична кров, яку забирали у стерильних умовах в моновети об'ємом 2,7 мл з калієвою сіллю етилендіамінтетраоцтової кислоти як антикоагулянта («Sarstedt», Німеччина). Геномну ДНК для молекулярно-генетичного дослідження виділяли $з$ лейкоцитів периферичної крові за комерційною тестсистемою «innu PREP Blood DNA Mini Kit» (Analytik Jena, Німеччина) з використанням відцентрових фільтрів.

Результати та їх обговорення. У 63 пацієнток обох досліджуваних груп, виявлено таку частоту генотипів: $A A-61,9 \% ; A C-30,16 \% ; C C-7,94 \%$. Розподіл генотипів у обстежених пацієнток відповідав закону Харді - Вайнберга та достовірно не відрізнявся від частоти генотипів за цим поліморфним варіантом, встановленим для представників європейських популяцій.

На рис. зображено частоту досліджуваних поліморфних варіантів гена у пацієнток обох груп.

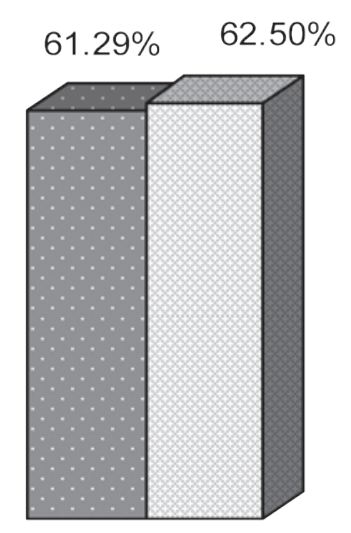

AA

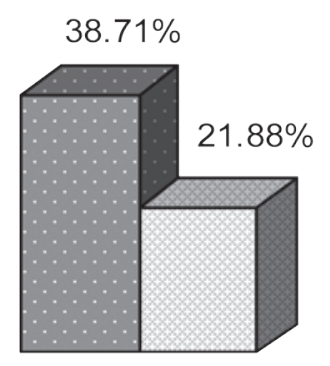

$\mathrm{AC}$

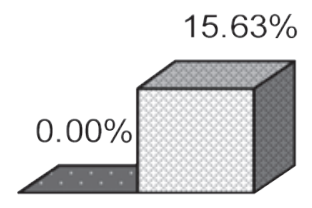

CC

Рис. 1. Частота поширення поліморфних варіантів гена $A G T R 1(A 1166 C)$ : $\square$ - хворі; $\square$ - здорові

Частота поширення генотипу $A A$ у хворих обох груп достовірно не різнилася $\left(\chi^{2}=0,03 ; \mathrm{P}>0,05 ;\right.$ ВШ $=0,95 ; 95 \%$ ДІ 0,34-2,63), спостерігали відмінності в пощиренні генотипу $A C$, частота якого становила $38,71 \%$ у пацієнток основної групи та 21,88\% у пацієнток контрольної групи, але зазначені відмінності були 
недостовірними $\left(\chi^{2}=1,39 ; \mathrm{P}>0,05 ;\right.$ ВШ $=2,26 ; 95 \%$ ДІ 0,75-6,82). У пацієнток основної групи взагалі не виявлено генотипу $C C$, а у пацієнток контрольної частота цього генотипу становила 15,63 \%. Наведені дані про частоту генотипу $C C$ були також недостовірними $\left(\chi^{2}=3,34 ; \mathrm{P}>0,05\right)$.

Побудова статистичних моделей передбачала включення до аналізу усіх даних обстеження жінок основної і контрольної груп. Загалом проаналізовано такі показники: індекс маси тіла, зріст та артеріальний тиск матерів, поліморфізм гена AGTR1, ембріометричні параметри (куприко-тім'яний розмір - КТР, ЧСС плода, об’єм плідного яйця - ОПЯ).

Комбінації усіх перерахованих показників використовували для побудови математичної моделі з найкращою класифікаційною спроможністю. Методом бінарної логістичної регресії визначено (табл. 1), що найвагомішими та достовірно значущими прогностичними маркерами загрози переривання у вагітних були ОПЯ і поліморфізм гена AGTR1 у математичній моделі, яка містила шість показників.

\section{Таблиця 1. Визначення прогностичних маркерів загрозливого переривання вагітності}

\begin{tabular}{l|c|c|c|c|cc}
\hline \multicolumn{1}{c|}{ Показник } & $\begin{array}{c}\text { Коєфіцієнт } \\
\text { регресії }\end{array}$ & $\begin{array}{c}\text { Стандартна } \\
\text { похибка }\end{array}$ & $\begin{array}{c}\text { Статистична } \\
\text { значимість }\end{array}$ & $\begin{array}{c}\text { Відношення } \\
\text { шансів }\end{array}$ & $\begin{array}{c}\text { Довірчі інтервали } \\
\text { 95 \% ВШ }\end{array}$ \\
\hline \hline Систолічний тиск & 0,045 & 0,074 & $-0,065$ & 0,088 & $-0,065$ & 0,088 \\
Діастолічний тиск & $-0,065$ & 0,088 & 0,459 & 0,937 & 0,789 & 1,113 \\
ЧСС ембріона & $-0,013$ & 0,017 & 0,46 & 0,988 & 0,955 & 1,021 \\
КТР,см & 2,536 & 2,519 & 0,314 & 12,631 & 0,091 & 1,058 \\
Об'єм плідного яйця & $-1,388$ & 0,463 & 0,003 & 0,25 & 0,101 & 0,619 \\
AGTR1 (АС) & 1,604 & 0,763 & 0,036 & 4,973 & 1,114 & 22,2 \\
\hline
\end{tabular}

Генотип $A C$ за умови зменшення ОПЯ збільшував ризик загрозливого переривання вагітності майже в 5 разів (ВШ =4,97). Для інших показників, зокрема КТР, ЧСС плода, рівень артеріального тиску в матерів, достовірного впливу на загрозу викидня у поєднанні з поліморфізмом гена AGTR1 не виявлено. Рівень гормонів фетоплацентарного комплексу та стан прозапальних цитокінів також не мали поєднаного з поліморфізмом гена AGTR1 впливу на загрозу викидня (за результатами інших математичних моделей).

Наведена статистична модель мала високу класифікаційну спроможність. Відсоток прогнозованої належності до основної або контрольної групи хворих, отриманих на основі статистичної моделі, що містила достовірні чинники - поліморфізм гена AGTR1 та показники ОПЯ, становив 77,8.

Ми оцінили також поєднаний вплив двох виявлених значущих чинників (ОПЯ та поліморфізм гена AGTR1) і з'ясували, що їх вплив підвищував ризик загрозливого викидня в 6 разів (ВШ =6,21; 95 \% ДІ 1,2- 32,3).

Враховуючи отримані результати про прогностичну значущість поєднаного визначення поліморфного варіанта гена AGTR1 та показників ОПЯ, ми проаналізували зв'язок між генотипом за досліджуваним геном і ОПЯ (рис. 2).

Середній показник ОПЯ збільшувався у 63 обстежених пацієнток від генотипу $A A$ до генотипу $A C$ і був найвищим у пацієнток з генотипом $C C$ порівняно 3 пацієнтками з генотипом $A A$, але зображене на рис. 2 підвищення середніх показників не було значущим. Отже, генотип матері за дослідженим геном не мав значущого зв'язку з ОПЯ у загальній групі обстежених і для цих факторів виявлено незалежний вплив на виникнення загрози переривання вагітності в ранні терміни гестації.

Важливі відмінності встановлено при порівняльному аналізі середніх показників ОПЯ у пацієнток основної та контрольної груп. У пацієнток контрольної групи з генотипом $A A$ був достовірно підвищеним $(\mathrm{P}<0,05)$ середній показник 
ОПЯ $\left(13,22 \mathrm{~cm}^{3} \pm 0,12 \mathrm{~cm}^{3}\right)$ порівняно 3 пацієнтками основної групи $\left(11,44 \mathrm{~cm}^{3} \pm\right.$ $\left.0,45 \mathrm{~cm}^{3}\right)$ із цим генотипом. Середні показники ОПЯ у пацієнток з генотипами $A C$ та $C C$ достовірно не різнилися в зазначених групах порівняння $-13,40 \mathrm{~cm}^{3} \pm$ $0,29 \mathrm{~cm}^{3}$ та $11,44 \mathrm{~cm}^{3} \pm 0,45 \mathrm{~cm}^{3}$ відповідно. Отже, при генотипі $A A$ у пацієнток контрольної групи спостерігалося значуще підвищення показника ОПЯ. При порівнянні середніх показників ОПЯ у пацієнток основної групи залежно від генотипів $A A$ та $A C$ нами визначено значущі відмінності $(\mathrm{P}<0,05)$. У вагітних основної групи з генотипом $A C$ середній показник ОПЯ становив $13,08 \mathrm{~cm}^{3} \pm 0,34 \mathrm{~cm}^{3}$, а 3 генотипом $A A-11,44 \mathrm{~cm}^{3} \pm 0,45 \mathrm{~cm}^{3}$.

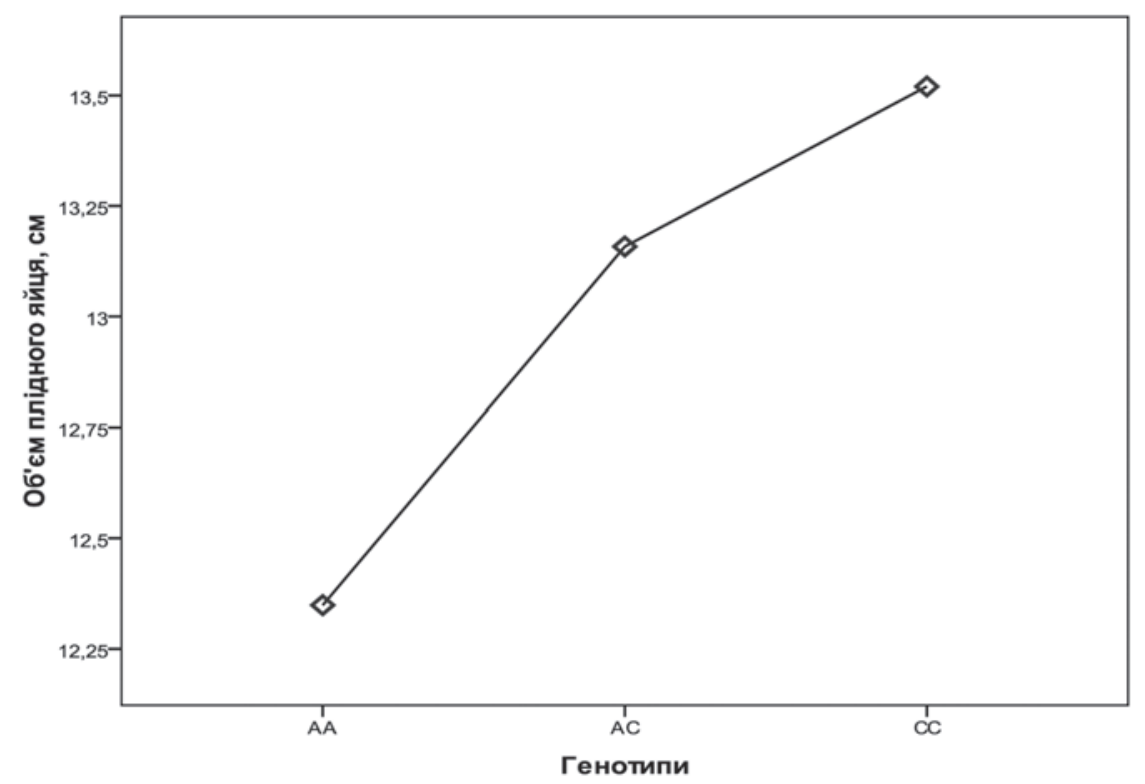

Рис. 2. Середні показники об'єму плідного яйця залежно від поліморфних варіантів гена $A G T R 1(A 1166 C)$

У пацієнток основної групи мали місце випадки завмерлої вагітності та її переривання на фоні загрози. Випадки передчасних пологів були в обох групах. Тому ми вважали за необхідне дослідити чинники тривалості гестації методом простої лінійної регресії.

Найкраща лінійна модель, що пояснювала залежність між гестаційним віком та 16 досліджуваними параметрами, наведена в табл. 2.

Таблиця 2. Визначення маркерів скорочення гестаційного віку у плода від вагітних з ускладненим та нормальним перебігом вагітності

\begin{tabular}{lcccc}
\hline \multicolumn{1}{c|}{ Показник } & Коефіцієнт регресії & $\begin{array}{c}\text { Стандартна } \\
\text { похибка }\end{array}$ & $\begin{array}{c}\text { Статистична } \\
\text { значимість }\end{array}$ \\
\hline \hline AGTR1(AC) & 5,637 & 2,128 & 0,01 \\
IgM & 21,76 & 15,288 & 0,16 \\
IL1- $\alpha$ & $-0,28$ & 0,148 & 0,063 \\
ЧCC ембріона & $-0,133$ & 0,046 & 0,006 \\
ХГ & 0,022 & 0,261 & 0,934 \\
\hline
\end{tabular}

Значуща лінійна модель включала п’ять показників. Важливими прогностичними чинниками скорочення гестаційного віку були поліморфізм гена AGTR1 та ЧСС плода. Остання при ускладненому перебігу вагітності та скороченні гестаційного віку становила 116,92 уд./хв $\pm 5,68$ уд./хв, а при нормальному перебігу 135,22 уд./хв $\pm 1,88$ уд./хв. Тобто ЧСС плода була значуще нижчою при скорочен- 
ні гестаційного віку $(\mathrm{P}<0,05)$. У 13 з 63 обстежених жінок з ранніми репродуктивними втратами та передчасними пологами, визначеними при подальшому спостереженні, виявлено переважно генотипи $A A(84,61 \%)$ та $A C(15,39 \%)$. Генотип $C C$ у цих вагітних не спостерігали.

Ми вивчали асоціацію між ОПЯ, генотипом AGTR1 із загрозою викидня у вагітних та виявили превалювання генотипу $A A$ у вагітних з ранніми репродуктивними втратами, які отримували токолітичну терапію, що вказує на необхідність подальших досліджень у цьому напрямі. Загалом материнський генотип $A C$ aсоційований із скороченням гестації, але кровопостачання та біометричні показники плода були кращими у разі його наявності. Потреба подальшого аналізу цих особливостей пов'язана з необхідністю розробки спеціальних підходів до застосування токолітичної терапії у вагітних із загрозою викидня та генотипом $A A$.

Висновки. Достовірним маркером виникнення загрози переривання вагітності є материнський генотип 1166AC за геном AGTR1, у разі наявності якого ризик появи загрози переривання в ранні терміни гестації збільшувався у 5 разів, а при одночасному впливі вищеперерахованих прогностичних факторів - у 6,25 раза. Генетичний аналіз материнського генотипу на 74 \% прогнозував загрозу переривання вагітності в обстежених жінок. Виявлення генетичних маркерів невиношування вагітності дозволить проводити ранню корекцію даної патології і запобігати перинатальним втратам.

\section{Конфлікту інтересів немає.}

\section{Список літератури}

1. Ботышева Т. Л. Стереофункциональные и хрониобиологические аспекты течения беременности // Вестн. Рос. ассоциации акушеров-гинекологов. - 2013. - № 2. C. $18-20$.

2. Демидов В. Н. Значение компьютерной ультразвуковой фетометрии в прогнозировании массы и роста плода на протяжении III триместра физиологически развивающейся беременности // Ультразвук. Діагностика в акушерстві, гінекології, педіатpiï. - 2011. - № 2. - C. 116-119.
1. Botysheva T. L. Stereofunkcional'nye i hroniobiologicheskie aspekty techenija beremennosti // Vestn. Ros. Assoc. akush.ginekol. - 2013. - № 2. - P. 18-20 (in Rus.).

2. Demidov V. N. Znachenie komp'juternoj ul'trazvukovoj fetometrii v prognozirovanii massy i rosta ploda na protjazhenii III trimestra fiziologicheski razvivajushhejsja beremennosti //Ul'trazvuk. Diagnost. V akush., ginekol., pediatrii. - 2011. - № 2. P. 116-119 (in Rus.).

3. Adamski Mateusz G., Golenia Aleksandra et al. Baird The AGTR1 gene A1166C polymorphism as a risk factor and outcome predictor of primary intracerebral and aneurysmal subarachnoid hemorrhages // Nefrologia I neurochirurgia Polska. - 2014. - Vol. 48, N 3. - P. 242-247.

4. Felix Stonek. The Role of Thrombophilia in Pregnancy // Reproductive Sciences. - 2012. Vol. 14, N 5. - P. 425-429.

5. Howard Carp. Maternal/newborn genotype contribution of the renin-angiotensin system (Met235Thr, Thr174Met, I/D-ACE, A2350G-ACE, A1166C-AT2R1, C3123A-AT2R2, 83A/GREN) to the risk of preeclampsia: a Romanian study // Hum. Reprod. - 2012. - Vol. 17, N 3. P. 23-25.

\section{ГЕНЕТИЧЕСКИЕ АСПЕКТЫ НЕВЫНАШИВАНИЯ БЕРЕМЕННОСТИ}

\section{К. Н. Лисовая, И. В. Калиновская, А. Н. Юзько (Черновцы)}

Невынашивание беременности является следствием влияния многих факторов. Мы проанализировали у беременных с невынашиванием в анамнезе влияние гена невынашивания на эмбриометрические, ультразвуковые, гормональные, иммунологические показатели и оценили его прогностическое значение. Основную группу составила 31 беременная, у которой были клинические признаки невынашивания данной или предыдущей беременности. Контрольную группу составили 32 здоровые беременные, клинико-параклинические показатели которых служили контролем для сравнения данных обследования беременных основной группы. Проведено общеклиническое и специальное акушерское обследование (выяснение жалоб, сбор 
анамнеза, общесоматический врачебный осмотр, акушерское обследование), биохимическое (определение гормонов фетоплацентарного комплекса в сыворотке крови беременных), ультразвуковое, иммунологическое, гистологическое исследование плаценты, молекулярно-генетическое исследование A1166C полиморфизма гена AGTR1. В процессе исследования выявлено генетическую детерминированность невынашивания. Полиморфизм A1166C гена AGTR1 рассматривали как прогностический маркёр прерывания беременности в ранние сроки гестации и преэклампсии во второй половине беременности. Достоверным маркёром угрозы прерывания у беременных был материнский генотип 1166AC по гену AGTR1. Риск возникновения клинических проявлений угрозы прерывания во время беременности увеличивался в 5 раз, а при комбинированном воздействии всех прогностических факторов - в 6,25 раз. Выявление генетических маркёров невынашивания беременности позволит проводить раннюю коррекцию данной патологии и предупреждать перинатальные потери.

Ключевые слова: невынашивание беременности; генетический маркёр; генотип; прогностический фактор; прерывание беременности.

\section{GENETIC ASPECTS OF PREGNANCY MISCARRIAGE}

\section{K. M. Lisova, I. V. Kalinovska, O. M. Yuzko (Chernivtsi, Ukraine) \\ HSEE «Bukovinian state medical university»}

Pregnancy miscarriage is a consequence of many factors. The aim of the study was to analyze the effect of miscarriage gene on embryometric, ultrasound, hormonal, immunological parameters in pregnant women, and to evaluate its prognostic value. The main group includes 31 pregnant women who had clinical signs of miscarriage in current or previous pregnancy. The control group consists of 32 healthy pregnant women whose clinical-paraclinical parameters served as a control to compare the data of the pregnancy survey of the main surveillance group. A general clinical examination and a special obstetrical examination (complaints, anamnesis, general medical examination, obstetric examination), biochemical studies (determination of hormones of the fetoplacental complex in blood serum of pregnant women), ultrasound, immunological studies, histological studies of the placenta, molecular genetic study A1166C polymorphism of the AGTR1 gene were made. In the course of the research, the genetic determinism of miscarriage was discovered. The polymorphism of the A1166C of the AGTR1 gene was considered as a prognostic marker of miscarriage in early gestational term and preeclampsia in the second half of pregnancy. A reliable marker of abortion was the maternal genotype 1166AC for the genome AGTR1. The risk of occurrence of clinical manifestations of abortion increased five times. At simultaneous influence of all prognostic factors the risk of abortion increased 6,25 times. Detection of genetic markers of pregnancy miscarriage will allow early correction of this pathology and prevent perinatal loss.

Key words: pregnancy miscarriage; genetic marker; genotype; prognostic factor; abortion. 